\title{
The Creation of Women from the Perspective of Mufassirun and Muhaddithun Between Past and Present Scholars
}

\author{
Roshimah Shamsudin ${ }^{1, *}$, Aiza Maslan Baharudin \\ ${ }^{1}$ Universiti Sains Malaysia
}

\begin{abstract}
The creation of women is under constant debate, not only among the Islamic scholars but outspreads to feminists both from the west as well muslims. This debate stems from the differing views of the preceding and contemporary scholars in interpreting the texts from the Quran and the Hadiths on the creation of human particularly Eve as the first woman created by Allah. The majority of the mufassirun and hadith scholars in the past pioneered the view that the origin of human; that Eve was created from the rib of Adam a.s. This view was regarded by the feminists as derogatory to women. The contemporary mufassirun and muhaddithun are however of the opposite opinion whereby Eve's creation was equal to that of Adam's a.s; thereby indicating that creation of Eve did not originate from Adam a.s. Hence this study was undertaken with the aim of reviewing the opinions of the tafsir and hadith figures by comparing the views between the past and present scholars in interpretation of Quranic texts as well as hadiths pertaining to the origin and creation of women. This study also extends to examining the arguments on which the opinions of each group were deduced.In order to achieve the above objectives, this qualitative form of study will employ data collection method, conducted through library research to obtain data relating to the origin of creation of women, in particular turath literatures in tafsir for example Tafsir Ibn Kathir and tafsir works by the leading tafsir scholars in the like of Syed Qutb; in addition to the past and present books on syarah hadith. The findings of this study show that the previous and present scholars of tafsir or hadith took different methodology in understanding both textual authorities.Unlike the previous scholars of tafsir and hadith, some of the contemporary scholars' understanding is that the texts are not to be construed literally; instead the texts need to be understood as parables and allegories thereby indicating that the creation of women is not from the ribs of Adam a.s.
\end{abstract}

\section{Introduction}

The issue of creation of women is not spared from intense discussion, particularly in the context of women's position to that of men. The issue stems from the view that women creation was derived from the rib of Adam. Wan Siti Nur Haini argues that the above view which had long been inherited and permeated into the psyche of most Muslims implicates the status of women which generally are regarded as second class citizens. The idea was reinforced by the existence of texts that show women were created from the ribs as evidenced by an authentic hadith narrated by Al-Bukhari and Muslim whose narrations form the two major hadith compilations that are consensually agreed upon by the hadith scholars as authentic, second only to the holy alQuran. Thus it is not unfathomable on why this women creation idea has lasting influence in the Islamic traditions.

Unfortunately, the notion that women was created from Adam's rib compromised women of their rights from various aspects such as religion, politics and social [25]. The denial of the rights of women according to
Halimah Basri is attributable to the concept that women are not created equal to men, and to top it off was created out of men as opined by certain mufassirun. In this context, she did not only associate this creation issues with the texts from hadiths alone but also links to the Quranic texts that were interpreted by past scholars

\section{Materials and Methods}

This qualitative study relies solely on library research. This means data was collected from primary scriptures from the books of tafsir and hadith. From the works of tafsir, data was taken from principal books of tafsir written by earlier scholars such as Tafsir Ibn Kathir, Tafsir al-Tabari, Tafsir al-Maraghi, books written by other contemporary tafsir scholars such as Muhammad Abduh and Rashid Redha and reference books of Tafsir written by a number of scholars from the archipelago such as Hamka, M. Quraish Shihab and Ahjmad Sonhadji. Data are also taken from key books of hadith such as Sahih al-Bukhari, Sahih Muslim and Jami' al-Tirmidhi and commentaries of hadith such as 
Fath al-Bari, written by Ibn Hajar and Sharh Sahih Muslim, authored by al-Nawawi. The data were then analyzed using the inductive, deductive and comparative method.

\section{Results}

In the context of creation of women, Halimatussa'diyah opines that the sources are mostly from the Israilliyyat, Torah, Bibble and Talmud compared to the al-Quran itself, whereby the latter does not even have clear absolute passages as evidence thereof. There are nevertheless three Quranic verses that led to the story of creation of women. For instance, verse 1: Al-Nisa'; verse 189: surah Al-A'raf and verse 6: surah Al-Zumar. However verse 1 of surah Al-Nisa' is more often quoted by mufassirun to prove the origin of women.

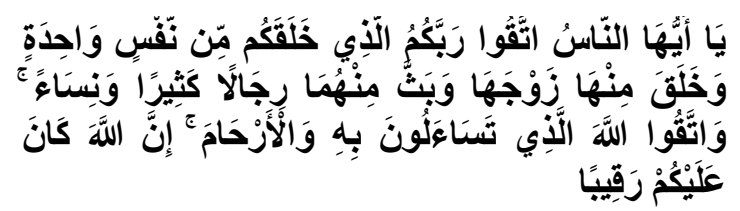

Meaning: O mankind, reverence your guidence Lord who created you from a single person, created of like nature his mate and from them twain scattered countless men and women.

I nere are three words that torm the basis of the creation of women namely wahidah, minha, and zaujaha all of which are given different interpretation by the mufassirun [6]. The differences had sparked disagreements among scholars of exegesis themselves. The ancient scholars in the likes of at-Tabari literally interprets min nafs wahidah to be referring to Adam while the word zaujaha refers to his spouse; Eve. In other words the verse, according to him shows that from a single Adam, Eve was created from his left rib to be his spouse. Al-Tabari further brings in the story of Eve's creation from Adam's rib while he was asleep as narrated by al-Suddi [23].

Al-Tabari's view is supported by a prominent mufassir such as al-Razi who not only opines that the creation of Eve was from Adam's left rib, but he also brings in a hadith to prove that Eve was created from Adam's bend rib. In spite of the detailed interpretation, al-Razi quotes the views of other scholars on the meaning of the said words. For instance Abu Muslim alIsfahani exegizes the word nafs to refer to the nature of Adam based on verse 72: Surah al-Nahl meaning Allah has made for you mates from your nature.Further to the above verse al-Razi also brings in a view from al-Qadi who rejects the interpretation of Abu Muslim. By alleging that if Eve was created from the nature of Adam, then this could infer that two beings had been created and thereby, the proper grammatical application in the Quranic text should be makhluqain min nafsain and not min nafs wahidah. The word $\min$ in the verse refers to the beginning of creation and hence dedicated to Adam.This discussion clearly demonstrates that the view of al-Razi is consistent with al-Tabari in interpreting the word nafs to be referring to Adam [17].
Ibn Kathir also concurs with al-Tabari and al-Razi on the origin of Eve from Adam's rib. As a leader exegesist who mastered the science of Hadiths, Ibn Kathir did not neglect to produce arguments from the hadiths to support his interpretations as is the case with al-Razi and asserts that since the hadith was narrated by Muslim thereby it indicates its authenticity in addition to having a sahih status and recorded in the grand hadiths compilation books. In addition, Ibn Kathir does not elaborate on the creation of Eve as does he on the creation of man from clay without a mother and a father, creation of Jesus from only his mother without a father and creation of mankind other than Adam, Eve and Jesus through the process of pregnancy. This discussion signifes that the creation of man can be understood from various dimensions based on its formative elements [10]. The same can be said of Suyuti who seems to have similar views to the scholars preceding him. However though the editor of his tafsir book by the name Fakh alDin opines that the hadith pertaining to the creation of Eve is indeed authentic, however, the texts are in the form of tamthil or parables to showcase the stubbornness of women compared to men [22]. Ibn Asyur too is found to have supported the notion that nafs wahidah to be referring to Adam from whose rib Eve was created as can be deduced from the word minha [8].

However al-Maraghi from amongst the ancient scholars have a dissenting view from the consensus of mufassirun. To him, mufassirun jumhur's interpretations are not based on the Quranic passages but instead are made on a natural basis that Adam is the father of humankind as mentioned in Torah. He however does not affirm whether he denies of concurs with this belief. He presents his exegesis by bringing in the opinions of a number of scholars who opine that nafs wahidah does not mean Adam but instead it means one single self or one single type. The word zaujaha means wife or spouse and the dhamir "ha" that is found in the word minha" refers to nafs wahidah which is defined as one type or from that very one type, that the spouse of Adam was created; and thereby means Adam and Eve were created from the same material, that is clay [13].

The view of al-Maraghi is in line with the views of certain present mufassir figures like Muhammad Abduh. The term min nafs wahidah according to him does not refer to Adam because preceding the term is the sentence wa baththa min huma rijalan kathiran wa nisa' that shows the term is in the form of nakhirah i.e not intended or devoted to any particular party. If the sentence were intended to refer to Adam, the correct sentence should be wa baththa min huma jami' al-rijal wa al-nisa. The creation of Eve from Adam's rib according to Muhamad Abduh is a story that is found in the Old Testament [1].

Echoing Muhamad Abduh's opinion, Rashid Redha comments that the phrase nafsin wahidah purpoted to be referring to Adamis not derived from Quranic texts but instead relied only on belief that Adam is the father of humankind. To him there is no absolute proof that suggests Adam is the forefather of humankind (Ridha 1367H)[18]. According to Halimatussa'diyah, the above mentioned verse that which understood by Rashid Ridha 
as men originating from the same substance and therefore the word nafs wahidah symbolises that human originates from humanly nature which welcomes goodness and rejects evil; and thereby negating the contentions that the verse is about the questions on the beginning of creations [6]. Al-Qasimi, the present mufassir figure in his work opines Eve was created from the human kind, and not from rib as per understood by scholars in the past [16]. Nevertheless, studies have found that not all the present exegesis scholars agree with the opinion of al-Maraghi, Muhammad Abduh and Rashid Redha, as evidenced by the interpretation of Said Hawwa which is in line with the consensus of ancient mufassirun in their views that the term nafs wahidah refers to Adam.

However, Said Hawwa is found to have quoted the view of al-Alusi which says Allah had created 30 Adams prior to the creation of the Adam who is demed as the father of humankind; with the time span of 1000 years for each Adam. Addition to that, Said Hawwa advises that the opinion of al-Alusi needs to be taken with cautions due to the fact that there are no authentic textual evidence to back the absurd version up. Said Hawwa further states that Allah is able to create Adam and Eve from clay but the reason why He created Eve and Adam was to prove his power that which is able to create being out of another living being [19].

A few contemporary scholars from the Malay Archipelago has also interpreted the same phrase. Among them is M. Quraish Shihab who views the old school scholars' opinions of Eve created from Adam has triggered negative thoughts among the muslim community giving rise to belief that women are created from men. M. Quraish Shihab cited the view alTabataba'i to give credit to his opinion that creation of Eve was from the same kind and not from Adam's rib [20].

Hamka joins the bandwagon with his own view. Hamka opposes opinions of the ancient scholars because he views that the term does not mention that the one soul as Adam with his partner Eve, created from his rib despite the preceding scholars the likes of Ibn Abas, Ibn Abi Shaibah, Ibn Jarir, Ibn Mundhir and Ibn Abi Hatim all opine to the contarary. Similar to Rashid Redha, Hamka views the idea of Eve being created out of Adam's rib is nothing more than a fairy tale plagiated from the Ibrani race and specifically the Jews from their Torah under the Book of Genesis [7]. Ahmad Sonhadji while interpreting this term had quoted al-Maraghi who stated that the scholars who interpreted nafs as Adam are basically not guided by the proofs contained in the Quran but only rely on mere beliefs that Adam is the father of mankind. He also comments that al-Maraghi argues using the historical relics like the discovery of human skeletal remains which predate the history of the existance of Adam [3]. Ahmad Sonhadji's view is in line with the opinion of Rashid Redha.

Besides, the discussion regarding the original creation of women has been in the attention of the muhaddithun since there exist in the master books of Hadiths, i.e alKutub al-Sittah the main and famous reference for Muslims, a considerable number of Hadiths that tell women were created from the rib. This hadith is found compiled in Sahih al-Bukhari, Sahih Muslim, Jami ‘ alTirmidhi, Musnad Imam Ahmad and Sunan al-Darimi, collective efforts by four companions namely $\mathrm{Abu}$ Hurayrah, Aishah Abu Dhar and Samurah. Al-Bukhari, Muslim and al-Tirmidhi record only narrations by $\mathrm{Abu}$ Hurayrah, while Ahmad bin Hanbal takes narrations from all four Sahabah. Al-Darimi on the other hand records narrations by Abu Hurayrah and Abu Dhar. Although the matan of the hadith is similarly narrated, however there is one difference in terms of the word (من) ضin dila'in and ka al-dila'i (كلع) that triggers a different understanding of the hadith as will be discussed further.

In the Sahih al-Bukhari, this hadith narrated by $\mathrm{Abu}$ Hurayrah is mentioned in three places. i.e in the Kitab al-Ahadith al-Anbiya' found in the chapter of the creation of Adam and his offsprings, and two hadiths in the kitab of al-Nikah in the chapter of doing good towards women. The matan of the hadith is as follows [2] :

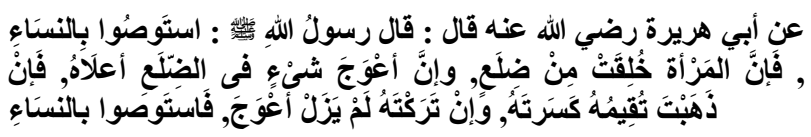

Meaning : Narrated Abu Hurayrah, Rasulullah said : Treat women nicely, for a women is created from a rib, and the most curved portion of the rib is its upper portion, so, if you should try to straighten it, it will break, but if you leave it as it is, it will remain crooked. So treat women nicely.

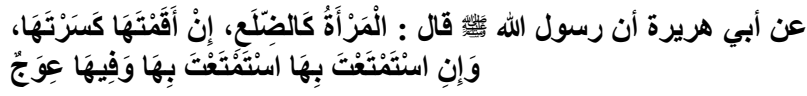

Meaning: Narrated Abu Hurayrah, Rasulullah said, "The woman is like a rib, if you try to straighten her, she will break. So if you want to get benefit from her, do so while she still has some crookedness.

Ibn Hajar in his book, Kitab al-Ahadith al-Anbiya' discusses a hadith narrated with a matan min dila in is found to have been using sighah tamrid which can be seen in the text قيل and can be understood as not from his absolute opinion. This means Ibn Hajar was aware that there are opinions that claim that Eve was created from Adam's rib and from other opinion from a short bend rib. In addition, Ibn Hajar quotes other narrations by Ibn Ishaq that there are additional attributes that is from the left rib before being sent to the heaven. Unsatisfied, Ibn Hajar further quotes the view of al-Qurtubi who opines that the hadith talks about women being created from the rib end thus it is like a rib. In Kitab al-Nikah, Ibn Hajar once again hinted the connection of this hadith with the narration of Ibn Ishaq; from Ibn Abbas that Eve was created from the short left most rib of Adam while he was asleep. Followed was the description on the meaning of the hadith; that is women were created from bend substance. This is not in conflict with the matan $k a$ al-dila ' $i$ afore mentioned equating women with rib. For Ibn Hajar, there is a common ground in the allegation 
that women temperament are bend like ribs because they originate from ribs [9].

Al-Kirmani when discussing this hadith in Sahih alBukhari states that women were created from bend rib. He further elaborate that this hadith is pertaining to the creation of the mere first woman Eve from the rib of Adam. He quotes the view of al-Tibi who says the gist of this hadith is somewhat akin to a will that demands compliance in discharging the rights of women and in furtherance to that encouragement to treat women well and to have patience with their temperaments 12].

Ibn al-Mulaqqin on the other hand in his book brings the view of Ibn al-Tin who views that mentioning the word rib in the hadith does not presuppose towards women but instead is a mere allegory to rib. Regardless, he still views that the rib women were created from is the left rib of Adam [11].

As for one hadith figure of the present day, Ibn 'Uthaymim when arguing a hadith narrated by alBukhari; elaborates that this hadith comes under the category of parables from the prophet s.a.w intended to mean that the prophet equates women with ribs because ribs are closest to a person. He concludes that this hadith is didactic in nature in which it expresses the need to interact with women who come in many forms; as wives, mothers, sisters in the most delicate and prudent way. He adds that the bend nature of women temperament if straightened will break because bend thing is unstraightenable [24].

Another contemporary hadith figure, al-Albani is also inclined to understanding this hadith in parable form. To him, this hadith is not to be taken literally or factually. His arguement is that there are no sahih and hasan hadith that expresses the creation of Eve from Adam's rib. It is in other categories of hadiths that the stories of Eve coming from Adam's rib are found expressive. As such, according to his evaluation, this hadith falls under munkar jiddan status because the sanad bears a narrator by the name Abdul Rahman bin Zayd whom the consensus of scholars judge as dhaif. As for the hadith that speaks about Eve being created while Adam was asleep is having a dhaif sanad and it is in fact a mauquf narration; whereby it was sourced from the companion and more inclined towards israilliyat. In addition, al-Albani brings in an arguement to corroborate his claim that narrations by al-Bukhari and Muslim are allegories in nature by the use of sigha al-tashbih found in the narrations i.e ka al-dila $i$ [4].

The view of al-Albani is consistent with that of Shu'aib al-Arna'ut, a present hadith scholar from Jordan who views the rib in question as merely parables that exemplify women's attitude that is bend and imperfect. This view is based on the term $k a$ al-dila' $i$ which he understands as a form of parables [21].

It is clear from the discussion of hadith on the creation of women is understood in two different meanings according to Muhaddithun, specifically literal understanding that women were created from the rib of Adam and secondly by allegory that women were created like a rib, refering to women's attitude that needs to be handled gently.

\section{Discussion}

The outcome of the discussions above regarding the creation of Eve from the al-Quran and hadith clearly shows that the earlier and the present mufassirin and muhaddithun held two differing perspectives. The majority of the earlier mufassirun and muhaddithun uphold the view that Eve was created from Adam's rib based on the following passages from the Quran نفس إن إن إن المرأة خلقت من الضلع and hadith واحدة وخلق منها زوجها

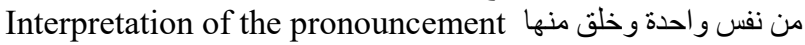
زوجها which they understood to be the reference to the creation of Eve was further reinforced by the hadith المراة خلقت من الضلع . Their views were contrary to the thoughts of some contemporary mufassir and muhaddith who believed that the creation of Eve did not originate from Adam's rib. The Quranic verses concerned are understood to mean that Adam and Eve were both created from the same substance which is the soil and there is also the view that they were both created equally in terms of humanity. The hadith is also understood to metaphorically describe women as the rib.

Although there are scholars who believe that there is a close link between the Quran and hadith that is seen as mutually supportive, there are also allegations of a difference of opinion between the two. This assertion is written by Qasim Qul Bek of Ibn Qimas who believes that the hadith written on the creation of women from the خلقكم من نفس و احدة rib of men contradicts the Quranic verse which to him meant that the creation of men and women are equal physically and intellectually. It does not mean that Adam was first created and from Adam, Eve was then created. In response to these allegations, Qasim Qul Bek stated that the word min in the Quran means to explain. It does not mean showing some parts as can be خلقلكم witnessed in some verses of the Quran, for example الله الذي خلقكم من ضعف and من أنفسكم أزواجا. Consequently, according to Qasim Qul Bek further, the verse carries this meaning that God created Eve from the same substance as that of Adam which is the soil and not from the light or fire from which angels and jinns were formed. In the context of understanding this hadith he is seen as emphasizing on this perspective that women are equated to a bent rib.

Thus, he stresses that true understanding of the meaning of the verse shows that there is no contradiction between the two. The researcher agrees with the view that there is no contradiction between the Quran and the hadith concerned as both are revelations and comes from the same source. Furthermore the hadith is a hadith which has been rated as authentic by al-Bukhari, Muslim and other figures, although there are claims that the source is from the Israiliyyat traditions, thus the concern for its legitimacy. Issues concerning the Israiliyyat and its connection to this hadith as well as Tafsir scholars' understanding of the Quranic verse related to the creation of Eve from Adam must be construed in the context that not all of the Israiliyyat tradition is rejected as prescribed by scholars. There is a category of the Israiliyyat that is seen as valid through the al-Quran and al-Sunnah. Grounded on this fact, the similarities between the al-Quran and al-Sunnah with the scriptures 
of the People of The Book are not a means to amaze to their fabricated scriptures as points of argumentation. Instead, this knowledge is grounded in divine revelation which is the al-Quran and al-Sunnah [14]. Therefore, the issue of ruling out the hadith and Tafsir of previous scholars of the Quran on the basis of Judaism are not sound.

In addition, not all the hadiths of the Prophet can be interpreted and understood literally. In this context, al-Qaradawi clarified that apart from the type of hadiths that are easily understood and clearly delineated, there are also hadiths which relies extensively on the use of Majazi in its sentences. This is due in part to the Arab culture of that era which uses a great deal of figurative speech. According to al-Qaradawi, Majazi sentences is made up of several forms such as majaz lughawi, majaz 'aqli, isti'arah, isti'arah al-tamthiliyyah and kinayah as spoken by the Prophet p.b.u.h. to refer to actions, words or certain conditions. An understanding of the hadiths of the Prophet in this form should be based on qara'in or specific instructions to engender to the true meaning 15]. Therefore, in the setting of the hadith concerning the creation of women from the rib, understanding of it should be in its figurative sense. Furthermore, there is also the qarinah which shows this fact using the word $k a$ al-dila' $i$ in other authentic hadith traditions.

\section{Conclusion}

The interpretation of the majority of earlier mufassirun and muhaddithun against the Quranic verses and hadiths which became the basis for discussing the origins of women and Eve, were found to conflict with the views of later muhaddithun and mufassirun scholars. The min nafs wahidah pronouncement which was understood by the early mufassirun as a mention to Adam and Eve and Eve's creation from Adam contradicts the interpretation of contemporary scholars who read its meaning as Eve being created out of the same substance as Adam. Also, the rendering of the present muhaddith is found to disagree with the reading of past muhaddith with regards to the creation of woman from the rib. This Hadith is understood to be a parable by the current muhaddith and this differs to the understanding of the past muhaddith who understands it as a fact. However, the contentions put forward by the present mufassir and muhaddith scholars is seen as stronger in discussing the origins and the creation of Eve.

Equations should be centred and should be numbered with the number on the right-hand side.

$$
\begin{gathered}
T_{\mathrm{s}}(l, t)=T_{\mathrm{g}}(l, t) \\
T_{\mathrm{s}}(l, t)=T_{\mathrm{g}}(l, t) T_{\mathrm{b}}(x \rightarrow-\beta, t)=0
\end{gathered}
$$

Use italics for variables $(u)$ and bold $(\mathbf{u})$ for vectors. The order for brackets should be $\{[()]\}$, except where brackets have special significance.

\section{Acknowledgement}

The research was done under Short Term Grant of Universiti Sains Malaysia, No 304/PHUMANITI/6313200

\section{References}

1. Abduh, Muhammad and Muhammad 'Ammarah. Al'Amal al-Kamilah. $1^{\text {st }}$ ed. Beirut: Dar al-Syuruq, (1993)

2. Al-Bukhari, Abi 'Abdullah Muhammad b. Ismail. Sahih al-Bukhari. $1^{\text {st }}$ ed. Beirut: Dar Ibn Kathir, (2002)

3. Ahmad Sonhadji Mohammad. Tafsir al-Quran (Tafsir al-Quran Di Radio). $2^{\text {nd }}$ ed. Kuala Lumpur: Pustaka al-Mizan, (1992)

4. Al-Albani, Muhammad Nasir al-Din. Silsilah alAhadith al-Da'ifah wa al-Mawdu'ah. $1^{\text {st }}$ ed. Riyad: Maktabah al-Ma'arif, (2004)

5. Halimah Basri. Penciptaan Wanita, Jurnal Studi Gender \& Anak, Vol. 5, No. 1. Indonesia: Universiti Islam Negeri (UIN), Makassar, (2010)

6. Halimatussa'diyah. Tafsir Kebencian : Studi Bias Gender Dalam Tafsir al-Quran Karya Zaitunah Subhan. Jurnal Ilmu Agama, Vol. 16, No. 1. Indonesia: Universiti Islam Negeri Raden, Palembang, (2015)

7. HAMKA. Tafsir al-Azhar. $1^{\text {st }}$ ed. Singapore: Pustaka Nasional PTE LTD, (1990)

8. Ibn Asyur, Muhammad Tahir. Tafsir al-Tahrir wa al-Tanwir. Tunisia: Dar al-Tunissiah, (1984).

9. Ibn hajar, Ahmad b. 'Ali b. Hajar al-'Asqalani. Fath al-Bari. $1^{\text {st }}$ ed. Riyad: Maktabah al-Malik Fahdi alWataniah, (2001)

10. Ibn Kathir, Ismail b. 'Umar b. Kathir al-Qurasyi alDimsyiqi and Sami b. Muhammad al-Salamah. Tafsir al-Quran al-'Azim. $1^{\text {st }}$ ed. Saudi: Dar Tayyibah, (1997)

11. Ibn al-Mulaqqin, Siraj al-Din Abi Hafs 'Umar b. 'Ali b. Ahmad al-Ansari al-Syafi'.Al-Tawdih li Syarh al-Jami' al-Sahih. $1^{\text {st }}$ ed. Qatar: Wizarah alAwqaf wa Syu'un al-Islamiyah, (2008)

12. Al-Kirmani, Muhammad b. Yusuf al-Kirmani Syamsuddin. Al-Kawakib al-Darari fi Syarh alBukhari (Syarh al-Kirmani 'ala al-Bukhari). $1^{\text {st }} \mathrm{ed.}$ Beirut: Dar Ihya' al-Turath al-'Arabi, (1981)

13. Al-Maraghi, Ahmad Mustafa. Tafsir al-Maraghi. Masr: Maktabah al-Mustafa al-Babi al-Halabi, (1946)

14. Qasim Qul Bek. Syubhah Wurud Hawla al-Ahadith al-Khassah bi al-Mar'ah. $1^{\text {st }}$ ed. Jordon: Dar alNafa'is, (2014)

15. Al-Qardawi, Yusuf. Kaifa Nata'ammul Ma'a alSunnah al-Nabawiyah. $2^{\text {nd }}$ ed. Kaherah: Dar alSyuruq, . (2002)

16. Al-Qismi, Muhammad Jamal al-Din and Muhammad Fu'ad Abd al-Baqi. Tafsir al-Qasimi Mahasin al-Ta'wil. $1^{\text {st }}$ ed. Masr: Dar Ihya' al-Kutub al-'Arabiyah, (1957) 
17. Al-Razi, Muhammad al-Razi Fakhr al-Din Ibn 'Alamah al-Diya' al-Din Umar. Tafsir al-Kabir wa Mafatih al-Ghaib. $1^{\text {st }}$ ed. Beirut: Dar al-Fikr, (1981).

18. Ridha, Muhammad Rasyid. Tafsir al-Manar. $3^{\text {rd }}$ ed. Masr: Dar al-Manar, (1367H)

19. Said Hawwa. Al-Asas fi al-Tafsir. $1^{\text {st }}$ ed. Kaherah: Dar al-Salam, (1985)

20. Shihab, M. Quraish. Tafsir al-Misbah : Pesan, Kesan dan Keserasian al-Quran. $1^{\text {st }}$ ed. Indonesia: Lentera Hati, (2000)

21. Shu'aib al-Arna'ut and Abi Zakariya b. Syaraf alNawawi. Riyad al-Salihin. $3^{\text {rd }}$ ed. Beirut: Muassasah al-Risalah, (2001)

22. Al-Suyuti, Jalal al-Din and al-Mahalli, Jalal al-Din. Tafsir al-Jalalain al-Muyassar. $1^{\text {st }}$ ed. Beirut: Lubnan, (2003)

23. Al-Tabari, Abi Ja'far Muhammad b. Jarir and 'Abdullah b. 'Abd al-Muhsin al-Turki. Tafsir alTabari Jami ‘ al-Bayan 'an Ta'wil ay al-Quran. $1^{\text {st }}$ ed. Kaherah: Dar Hijr, (2001)

24. Al-'Uthaymin, Muhammad b. Salih and Muhammad Nasir al-Din al-Albani. Syarh Sahih al-Bukhari. $1^{\text {st }}$ ed. Kaherah: Maktabah al-Islami, (2008)

25. Wan Siti Nur Haini. Penciptaan Wanita Dari Tulang Rusuk (Studi Kritis Tentang Hadis Penciptaan Wanita Dari Tulang Rusuk). Semarang: Institut Agama Islam Negeri Walisongo, (2013) 